\title{
Higher Education in Serbia: From Socialism to the Free Market Economy and Implications for the Labour Market
}

\section{LIDIJA SMIRNOV}

This paper focuses on the relationships between higher education and the labour market in Serbia. In order to understand this relationship better, this paper will first provide a brief history of the country and the history of its higher education structures. The paper will then discuss higher education from post Second World War until the fall of communism, highlighting how tertiary education met the goal of preparing young people for life in a socialist economy. The second part of the paper will discuss higher education after the fall of communism, and will show how higher education is not inadequately preparing Serbian graduates for the needs not only of the free market, but the new global economy.

\section{Brief Country History}

Serbia has had a long and turbulent history. It has been through two Balkan Wars, two World Wars, a civil war and numerous uprisings throughout the last two hundred years. It emerged as an independent nation in 1804, after five hundred years under the Ottoman Empire's rule. In 1918 it joined together with Croatia and Slovenia to form the Kingdom of Serbs, Croats and Slovenes. The country was later renamed the Kingdom of Yugoslavia. After the Second World War, it became part of the Federal People's Republic of Yugoslavia, which in 1963 changed its name to the Social Federal Republic of Yugoslavia (further SFRY). It consisted of six republics (Slovenia, Croatia, Bosnia and Herzegovina, Montenegro, Serbia and Macedonia) and two autonomous provinces both in Serbia (Vojvodina and Kosovo). Although it was a communist country, this was not the harsh form of communism other countries in Eastern Europe experienced. A self-management style of governance led the country, which essentially meant that workers themselves were managing production. In 1991 the country started disintegrating. Slovenia was first to secede from the union, followed by Croatia and Bosnia and Herzegovina, with Macedonia following shortly thereafter. Up until March 2003 the country's name was the Federal Republic of Yugoslavia, with the only republics in the union being Serbia and Montenegro. Then it was changed to Serbia and Montenegro. In May of 2006 the Montenegrin people voted for independence in a referendum. Perhaps ironically, at the beginning of the twentyfirst century Serbia finds itself socio-politically where it was two centuries ago - a sole, independent nation.

\section{History of Serbia's Higher Education}

Education was very much neglected during five centuries of Ottoman Empire domination (1355-1804). People were educated informally, in monasteries and by 
priests in villages. The consequences of this type of schooling were rather staggering. Illiteracy was widespread and 95 per cent of the population was classified as farmers (Avramović, 2003, p. 172). Independence in 1804 brought many changes to Serbian education. Driven partly by nostalgia and, partly, patriotism, many foreign-educated Serbian scholars returned to the country. Their contributions to the development of education are countless and well-documented. Dositej Obradovic was just one notable returning scholar, who created the first school in Serbia and who eventually became the country's first minister of education.

Education was on a fast track during the nineteenth century and the country managed to significantly increase the level of literacy to just below 50 per cent by the end of the Second World War (Avramović, 2003, p. 47). Serbia, together with other parts of the Kingdom of Yugoslavia, suffered heavy losses in the First and Second World Wars, both in human life and infrastructure terms. About 14 per cent of schools were destroyed, while over a third were badly damaged (Jemuović, as quoted in Grant, 1969, p. 307).

Higher education in Serbia developed from the so-called Visa Škola (Higher School), which was created at the beginning of the nineteenth century. Nevertheless, the first real university did not open until 1905, in the form of the University of Belgrade. It was another half a century, before another university - the University of Novi Sad - opened in 1960 .

No Federal Ministry of Education existed after 1970 (Uvalić-Trumbić, 1990), as the Constitution of 1974 put each republic and autonomous province in charge of education in its territory, resulting in eight ministries of education in SFR of Yugoslavia. The legal governance of higher education was somewhat perplexed, as two different laws governed higher education and other post-secondary education institutions.

With the fall of communism and the dissolution of the country, higher education in Serbia embarked on a new wave of change. The last decade of the twentieth century was characterised by political and economic sanctions. As the country became isolated from the rest of the world, so were its students and universities. In 1998, during the Milosević regime, a new Higher Education Law was passed, which shamefully took away all academic freedom. Under the law, the federal government elected and removed rectors, deans and professors, and hundreds of academics lost their jobs. After the fall of the Milosevic regime, a new, more democratic law quickly replaced it, and academic freedom was once again returned to the hands of institutions of education.

In 1990, just before the break-up of SFRY there were a total of nineteen universities in the country. Today in Serbia, there are seven state universities, seven private universities and six specialised faculties (colleges) not associated with a university.

\section{Structure of Higher Education: Post Second World War to 1991}

In this period, higher education institutions were composed of university and nonuniversity sectors. The university sector included all universities, which consisted of faculties or colleges, for example the College of Natural Sciences and Mathematics (Prirodno-Matematicki Fakultet), the College of Education (Pedagoski Fakultet), the College of Social Sciences (Filozofski Fakultet), etc. These faculties, however, were all 
independent entities rather than part of a university as a whole. They hired their own staff and faculty, set enrolllment policies, and decided on the curriculum for their fields of study. The non-university sector included two-year post-secondary institutions (Vise Škole), vocational schools and teacher training colleges.

Higher education in the communist period was not part-time friendly. As matter of fact, part-time students were referred to as 'special' (vanredni). There were not many of them and those who did study part-time did so because they were working full-time. While education for full-time students was provided at no charge, part-time students did pay fees, which were generally covered by their employers. It is also worth mentioning that higher education institutions had primarily an academic-teaching function. Research did not fall within their scope of responsibility and was done at institutions not associated with higher education.

Until the early 1950s, access to higher education was open to anyone who completed the secondary level. However, in the 1951/1952 academic year, entrance quotas and examinations were introduced (Uvalić, 1954). The enrolment procedure was such that students would apply not to a university, but directly to a faculty. For example, if they were interested in studying mathematics, or any of the natural sciences (biology, geography, etc.), they had to apply to the Faculty of Mathematics and Natural Sciences. Consequently, an eighteen or nineteen-year old had to have some idea of what he or she wanted to study before even applying. This was not the first time students were forced to think about their future careers. Specialisation took place much earlier, at the secondary level. Those who knew they wanted to continue to university would enrol into gymnasiums (gimnazija), which provided general education. Most others would go to specialised, vocational secondary schools, which did have tracks that allowed some pupils to continue further to the university level.

The subjects on the admissions test depended on the faculty, but often had a general knowledge/intelligence component, and each faculty had its own admission board that administered the testing. The results were posted as ranks, based on the number of points students obtained on the exam. In addition to this all higher education institutions required that students complete certain subject in high schools, before they could qualify for admission to higher education.

The first year of university studies met the general-education requirement, after which students had to choose which specific track they wanted to follow. These tracks were very narrow and specialised. For example, the student had to decide between a 'teacher of biology' or just plain 'biology' tracks. There was no mobility within different fields or faculties, and switching majors was almost impossible, as each had a specialised curriculum. This inflexibility was not only obvious within the faculties, but in the entire higher education sector. Universities and other post-secondary education institutions were not connected nor did they complement each other. The system did not offer students the possibility to transfer and/or continue studies further, after for example obtaining the Associate Degrees from a Visa Škola.

Course schedules were also pre-set and generally students from the same track had the same course schedule. Courses included lectures, seminars, colloquium and a final exam, which was an oral test in front of one or more professors. Students would draw three questions and had to provide satisfactory answers to each of them in order to pass.

Undergraduate education was intended to last four years, but some programmes such as engineering and medicine had official curricula of between five to six years. As the table below shows, in practice this was much longer. 
Table 1. Actual length of time (Years) it took to obTain a Degree (1985)

\begin{tabular}{lcccccc}
\hline \hline Subjects & Math/Science & Technical & Medicine & Biotechnology & Social Science & Arts \\
\hline Years & 6.76 & 7.64 & 7.28 & 7.14 & 6.70 & 5.62 \\
\hline \hline
\end{tabular}

Source: Ivić, 1992.

Post-graduate studies generally lasted two years; however, there was little structured course work. Whether or not there were any classes for students often depended on the institution, the field of study and the professors. Nevertheless, students needed to complete a research project, either independently, or under a supervision of a professor-mentor. Doctoral studies, on the other hand, had no coursework at all. Candidates simply had to complete an independent research project, write a dissertation, and defend it successfully.

\section{Higher Education and the Labour Market: Second World War to 1991}

Although communism was not nearly as extreme in SFRY as in the rest of Eastern Europe, communist ideology was very much present in the education sector, as well as the labour markets. According to Soljan (1991): "the objectives of higher education in Yugoslavia during the last few decades have focused mainly on the preparation of young people for work and for life in an industrial society of a socialist orientation" (p. 144).

The labour market guaranteed lifetime employment, where firing was often illegal, and salaries bore little relation, if any, to education and skills. It is not surprising then that doctors and lawyers had salaries often similar to manual workers in the manufacturing or other industries. Collective achievement was more important than the individual one. With self-management principles, workers had full control over operations of an enterprise and production. In line with this type of governance, SelfManagement Communities of Interests were put in charge of higher education (Soljan, 1991, p. 142). Their members came not only from higher education institutions, but also local employers.

Professors acted with high authority in classrooms. Questioning of concepts and ideas was not allowed. Education was not supposed to develop freethinking or critical analysis in an individual. Hence, just as students were expected to be submissive to the teaching staff, the entire higher education acted the same way towards the labour market. The education reforms of 1974 strengthened this bond. The labour markets completely dictated their needs to education; quantity rather than quality of education mattered more, and research was completely separated from universities (Ivić, 1992, p. 113). Each job demanded specific educational attainment, and the minimum required levels of educational attainment were specified in job announcements by levels. Job vacancies not only indicated the required levels of education, but also the particular tracks. Those who did not finish the track 'teacher of biology' could generally not apply to positions in teaching. Higher education did not offer programmes or options for those not in the teaching track to become certified for these positions.

The national economy was calling for specialists in various disciplines rather than people with general knowledge. For example, in the field of economics, the Federal 
Law of 23 July 1974 called for "specialised economists, planners, statisticians, and financial and commercial experts..." (Uvalić, 1954, p. 265). The curriculum of higher education assured that students received the particular degree that met these demands. If somebody wanted to be an Economic Specialist, a Planning Specialist or an Economic Statistician, he needed to have a Licentiate of Economics or Law (p. 265). Most of the curriculum in economics consisted of theoretical courses as they related to a socialist planned economy.

With this tight relationship between higher education and the labour market, it is not surprising that they shared many similar features. The former had no provisions for part-time studies, while the latter did not allow part-time, or other flexible types of employment. Just as switching majors at the university was difficult, changing professional careers was neither expected, nor encouraged. People generally spent thirty to forty years working in the same company. In this respect, the higher education was aligned perfectly well with the needs of the socialist economy, as it was preparing young people for one particular profession (zanimanje). The goal upon graduation was to find a job and work 'in the field' (raditi u struci), the field being the very same subject matter the individual had studied.

Nevertheless, the weakening economic situation created surplus labour, both among low-skilled and highly-educated persons. Many university graduates started to look beyond Serbia's borders, for employment opportunities. The technological revolution increased the need for highly-skilled individuals and this can be seen in emigration patterns from Serbia in the 1980s.

\section{Higher Education and the Labour Market (1991-2000)}

The last decade of the twentieth century was a very dark time period for the country. Civil wars were raging in Bosnia and Croatia. Yugoslavia (Serbia and Montenegro) was cut off from the world with political and economic sanctions. Inflation was so high that prices often changed daily. Private universities started opening up and new disciplines, such as business and management, emerged. Fees were also imposed at state universities, due to the country's inability to finance them (enrolment fees, exam fees, etc.). There were issues with heating in classrooms, availability of teachers, low salaries and overall low morale. The structure of education did not change much and actually remained in the same shape and form as the pre-1991 period. However, the lack of finances impacted the quality of educational infrastructure, the availability of books, equipment, etc. Students had a very difficult time studying and completing their studies. Both the GDP per capita and the expenditure on higher education were cut into half (Ministry of Education and Sports, 2006), the University Law of $1998^{1}$ completely abolished the autonomy of the university. The government fired many teachers and appointed new ones, including deans, rectors, all of whom were politicians and/or friends of them.

With the economic and political sanctions and civil war in bloom, the labour markets were in distress. There were massive layoffs, with the closing of factories and companies, resulting in large scale unemployment. Young people did not feel there was a future for them in the country and many emigrated elsewhere. Some estimates suggested that as many as half a million young people left the country during this time. Unfortunately, it may never be clear as to how many actually left, because the country did not keep track

\footnotetext{
${ }^{1}$ Available at <http://www.hrw.org/reports/1999/serbia/Serbia99-03.htm> and <http://hrw.org/english/ docs $/ 1998 / 12 / 21 /$ serbia1456.htm $>$.
} 
of migration figures. It is clear though that those young people who stayed were trying to cope with the harsh circumstance both in education and the labour markets.

\section{Higher Education (2000-Present)}

On 5 October 2000, the people in Serbia staged an uprising and overthrew the Slobodan Milosević regime. This event paved the way for widespread changes in society including the education sector. A new Ministry of Education and Sports was formed in February 2001 and it immediately made steps for reforming education, from primary to post-secondary level.

Having study programmes which were relevant to the labour market was just one of the goals of higher education reforms (Ministry of Education and Sports, 2002, p. 281).

Ten years of isolation and sanctions had a profound impact on higher education and its infrastructure. In 2002, the European University Association performed an overall analysis of the universities in Serbia. Their findings were grim, but not new to the people and students in the country: aged and out of date curriculum and teaching methods; too much emphasis on theoretical knowledge; very low graduation rates; an overwhelming number of exams; and the existence of corruption, were among the findings.

Between 2001 and 2005 there were very few changes and reforms actually implemented. During this time the rest of Europe was on track to creating 'The European Higher Education Area' (EHEA). Serbia officially joined the Bologna Process, in September 2003. However, without new legislation, adapting to and implementing the Bologna provisions was not possible. The assassination of Prime Minister Zoran Djindjić, in March 2003, led to new changes in political circles. Between 2001 and 2006 there had been three Ministers of Education, yet a New Higher Education Law was finally adopted in late August 2005. Nevertheless, changes have been slow in coming and have come from the initiative of individual universities.

Today higher education, just like all other levels of education is centrally managed from the Ministry of Education and Sports, located in the capital, Belgrade. Until very recently, the structure of tertiary education has remained similar to that of the socialist period. School year 2006/2007 marked a first, when all universities officially started programmes that are aligned with the provisions of the Bologna Declaration. There are also quite a few new disciplines and with the establishment of private universities, the state ones have been faced with competition for the very first time in their history. It is debatable though how much this competition has contributed to an increases in the overall quality of education. There are many issues in the higher education system: efficiency; corruption; and financing being just some of them. The duration of studies, on the other hand, has been particularly disturbing. The numbers in Table 2 below show an increase compared to that of 1985.

TABLE 2. Length of TIME TO COMPLETE AN UNDERGRAdUATE DEGREE AT UNIVERSITIES IN SERBiA (2005)

\begin{tabular}{lcccccc}
\hline \hline Subjects & $\begin{array}{c}\text { Natural Sciences } \\
\text { and Math }\end{array}$ & Technical & Medicine & Biotechnology & $\begin{array}{c}\text { Social Science/ } \\
\text { Humanities }\end{array}$ & Arts \\
\hline Years & 9.17 & 10.23 & 11.03 & 7.14 & 8.69 & 8.58 \\
\hline \hline
\end{tabular}

Source: Ministry of Education and Sports, 2005. 
Perhaps, one explanation of the prolonged studies can be found in these words:

Due to a lack of better means for evaluating institutions, the success of former students in their graduate studies in world-renowned universities became the only applied criteria. Setting this as a goal each university started revising its curricula, adding more and more subjects to it until it covered the undergraduate and graduate level. Left without a choice, students have been trying to cope with this... (Ministry of Education and Sports, 2003, p. 17)

\section{The Failure of Serbian Higher Education to Prepare its Young People for the Twenty-first Century Labour Market}

Serbia has a very low percentage of people with first cycle higher education qualifications - roughly 11 per cent, while the percentage of those with graduate or doctoral degrees is even lower. The overall level of education attainment of Serbia's population is lower than that of other transition countries in the region (World Bank, 2004, p. 118). Furthermore, the Labour Force Survey (LFS) in 2002 showed university graduates have a twice as high unemployment rate to those with less than primary education (World Bank, 2004, pp.97-98). At the same time, people with primary and secondary levels of education comprise almost 80 per cent of those employed, compared to only 8 per cent of those with tertiary education (World Bank, p. 98). It is not surprising then, that much of Serbia's industry is concentrated in areas that demand unskilled, physical labour.

With the disappearance of communism fifteen years ago, the idea of lifetime and guaranteed employment also disappeared. However, the Serbian labour market has been very slow in implementing the flexibility needed for the free market system. Parttime, contractual work, and more lenient regulations regarding hiring and firing have only been defined and introduced in the labour laws for a few years.

The transition from the socialist to the free market economy has also meant changes in the need for new labour. Added to this, the last decade of the twentieth century was a true information age revolution, with Internet and communication businesses mushrooming. All this means that the transition economies had to reform their education system, not only to fit the free market economy, but also at the same time the new information age. Soljan stated, fifteen years ago, that in the global, ever-changing world the task of higher education is "not to prepare an individual for a single career" or to "provide knowledge and skills in one area" (Soljan, 1991, p. 144). Table 3 below outlines how the transition from a centrally planned to the free market economy impacted the type of skills needed for new labour market.

The previous section of this paper showed how in the socialist era higher education in Serbia equipped young people with 'old skills' (as per Table 3), which were exactly the skills needed for the labour market at the time. The question becomes: to what extent does higher education in Serbia today help young people acquire the new skills needed for the labour market. In attempting to answer these questions one can begin by analysing how higher education today contributes to and allows for the development of 'new skills'.

The structure of higher education today is not much different from that of ten or fifteen years ago, which means there is not much flexibility in it to start with. When students enroll they have to choose the particular faculty and decide upon the 
TABLE 3. TABLE OF COMPARISON OF SKILLS NEEDED IN THE LABOUR MARKET

\begin{tabular}{ll}
\hline \hline \multicolumn{1}{c}{ Old Skills } & \multicolumn{1}{c}{ New Skills } \\
\hline Apply knowledge acquired by rote & Apply problem-solving strategies \\
Use invariant sources of information & Acquire, evaluate information from diverse courses \\
Work as a solo practitioner & Work as a collaborator or member of a team \\
Operate in routine, unchanging ways & Operate in a flexible, self-correcting way \\
\hline \hline
\end{tabular}

Source: Kerr (2002), reproduced from Table 6.1 in Agenda for Economic Growth and Employment, World Bank, 2004 (p. 120).

track-major they want to study and graduate from. Recalling that a few decades ago students began their studies with a general education programme in their first year and then decided upon their majors by the start of the second, it can be argued that the system today is more rigid then it was before. Changing fields of study is not easier today than it was twenty yeas ago. In this respect, the system itself does not represent a flexible learning environment.

Further, when students start their university studies, their programme and curriculum are already decided for them. There is no choosing the class schedule, or classes. Departments within each faculty prepare the class schedule, which all students in the particular major are supposed to follow. The prescribed curriculum states what courses are supposed to be taken, in what semester of study, and in what order. Deviations from this are not possible. In this manner the students are not required to try to figure out the type of courses they need to take for either general education requirements, or their majors; they do not have to worry about trying to fit a certain class in their schedule, or calculate the number of credits they have to check if they can graduate. Although it may seem nice that students have little to worry about, this system actually resembles a very centrally planned system. Indeed, it hardly teaches students any sense of responsibility or problem solving skills. All they have to do is follow the recipe.

Moreover, most of the classes are still mandatory. Even if there are electives, these 'electives' hardly deserve the definition. Firstly, 'elective' courses are clearly designated and students actually have very little choice in deciding whether or not to take them. In many majors the curriculum indicates 'Elective A' or 'Elective B', only to find, at the end of the curriculum, the list of electives (A, B, C, etc) with the names of courses they refer to. Not only that, but the electives are strongly linked to the field of study. For example, out of the six electives posted on the programme of study for a 'Professor of Physics' track, at the University of Novi Sad, four are physics related with three being 'physics of...' and the fourth one is about astronomy. Most other fields of study, besides a foreign language, follow the similar pattern of electives, if they have them at all. This type of curriculum fails to help students 'acquire or evaluate information from diverse courses', one of the 'new skills' needed.

Examinations are still oral and are more a test of memory than knowledge. They resemble a lottery as students draw questions from a hat as they have done for decades. They mostly ask students for definitions of theories, concepts, rather then asking them to apply and analyse them critically. Furthermore, many professors are also inclined to fail students on exams if they say something that does not reflect the professor's ideology. This kind of attitude shows that routine and conformity are preferred to innovative and analytical skills and there is not much room for tolerance of differences. 
At the same time, higher education in Serbia is not preparing its young generations for the diversity of the modern labour market by not allowing students to be exposed to different groups of students outside their fields of study. The technological revolution has made it easier to communicate and cooperate with people from diverse cultures, values and beliefs. Yet, university studies in Serbia offer very little experience of this. Students from different majors (fields of study) do not have classes together. Students from different faculties do not mingle together in or outside classrooms, as each faculty has a separate building where classes are held. Since the students follow a pre-set curriculum they end up spending their studies in a classroom with more or less the same group of students. This method does give an opportunity for forming close relationships, but does not help students acquire any cross-cultural or diversity skills, nor does it help them develop a sense of need for adaptation to different environments.

\section{Conclusion}

Tertiary enrolment statistics over the last several decades would have substantially enriched the analysis of the higher education-labour market relationship, presented in this paper. Unfortunately, and interestingly enough, the Ministry of Education does not have data on tertiary education. Nevertheless, this paper showed how the characteristics of the labour market were mirrored in higher education during the socialist times. Changes, which the transition period forced in both areas, have been rather slow and many fundamental problems remain, especially in higher education. Its rigidity does not allow young people in Serbia to attain the skills needed for the modern labour market. The length of studies, on the other hand, prevents them from being active participants in the labour market, as early as they can. Yet, 'brain drain' today is perhaps more severe than it has ever been and the country is in desperate need of educated, skilled people.

Serbia's goal, to become a "modern, European nation", dates back to the nineteenth century (Avramović, 2003, pp. 44). It appears the country has gone back in time, both socio-politically and economically. The question remains: Will Serbia recognise the important role of higher education in its national development? Will it move forward, or remain what Grant (1969) called "one of the most backward countries in Europe" (p. 330)?

\section{Acknowledgement}

The author would like to thank Judit and Vladimir Smirnov, Dragana Ilić, Jelena Jović, Jelena Ognjnaović, Ljiljana Ognjanović and Ivana Pejnović for their contribution to this paper.

\section{References}

Avramović, Z. Dva Veka Obrazovanja u Srbiji [Two Centuries of Education in Serbia]. Beograd: Institut za Pedagoska Istrazivanja, 2003.

EuropeAn University Association. (2002). "Institutional Evaluation of Universities in Serbia 2001-2002". Retrieved on 10 October 2006, from <http://www.ns.ac.yu/stara/novosti_dogadjaji/evaluacija/opstiSr.pdf>, 2002.

Grant, N. Society, Schools, and Progress in Eastern Europe. Oxford: Pergamon Press, 1969. 
Ivić, I. "Recent Developments in Higher Education in the Former Federal Republic of Yugoslavia", European Journal of Education 27 (1992): 11-120.

Ministry of Education and Sports, Serbia. "Kvalitetno Obrazovanje za Sve - Put ka razvijenom Drustvu" [Quality Education for All - Road Towards a Developed Society]. Belgrade: Ministry of Education and Sports, 2002.

Ministry of Education And Sports, Serbia. "Higher Education in Serbia and the Bologna Process". Retrieved on 11 October 2006, from Conference of European Ministers responsible for Higher Education Web Site <http://www.bologna-berlin2003.de/pdf/Serbia.pdf>, 2003.

Ministry of Education AND SpOrts, Serbia. "National Reports 2004-2005 Serbia. Retrieved on October 11 2006, from Bologna Process Bergen 2005 Web Site <http:// www.bologna-bergen2005.no/EN/national_impl/00_Nat-rep-05/National_Reports-Serbia_ 050121-m.pdf>, 2005.

Ministry of Education And Sports, Serbia. "The Development of Education: National Report of the Federal Republic of Yugoslavia - Serbia". Retrieved on 20 June 2008, from $<$ http://www.ibe.unesco.org/en/access-by-country/europe-and-north-america/republic-of-serbia/ profile-of-education.html>, 2006.

Soljan, N. "The Saga of Higher Education in Yugoslavia: Beyond the Myths of a SelfManagement Socialist Society", Comparative Education Review 35 (1991): 131-153.

Uvalić, R. "The Teaching of Economics in Yugoslavia", in, The International Economic Association, The University Teaching of Social Sciences: Economics. Paris: UNESCO, 1954, pp. 262-281.

Uvalić-Trumbić, S. "New Trends in Higher Education in Yugoslavia?" European Journal of Education 25 (1990): 399-406.

World BAnK. "Serbia and Montenegro, Republic of Serbia: An Agenda for Economic Growth and Employment". Report No. 29258-YU, 2004. 
Copyright of Higher Education in Europe is the property of Routledge and its content may not be copied or emailed to multiple sites or posted to a listserv without the copyright holder's express written permission. However, users may print, download, or email articles for individual use. 